\title{
Public Domain in Dispute Settlement of Cancellation of Industrial Design Rights
}

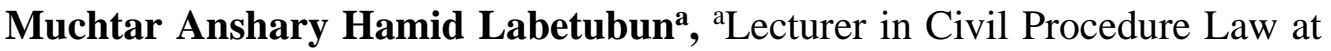
the Faculty of Law, University of Pattimura, Ambon, Indonesia, Email: amahlabetubun@gmail.com

Economic rights in Industrial Design have protection that is limited to a period of 10 years. After the expiration of protection, Industrial Designs that previously owned exclusive rights by the holders of rights to Industrial Design become public property; so that the Industrial Design has no obligation to ask permission to the rights' holders for Industrial Design to use the Industrial Design. This is generally referred to as Public Domain, as stipulated in Article 2 paragraph (1) and (2) of Law Number 31 Year 2000 concerning Industrial Design, that "Design rights Industry is granted for a new Industrial Design, Industrial Design is considered new if on the date of Acceptance, the Industrial Design is not the same as pre-existing disclosures". So basically, Industrial Design has a new principle. However, in reality, there are several cases of Industrial Design in resolving disputes over Industrial Design rights that have been registered, because the Industrial Design has become Public Domain, and there has been a cancellation of Industrial Designs including Cases: Industrial Design of Oil Bottles, Industrial Design of Lighters, Industrial Design of Packaging Boxes 4 (Four) Square, Industrial Design CBK 124 Cabinets, Garuda Motorcycles, Industrial Design Disk Places, Industrial Socks Design, Industrial Design Folding Iron Door Chains and Folding Iron Door Leaves, X2 Shoe Strip Industrial Designs, and Industrial Design TMS Roll Forming Machines Machine.

Key words: Public Domain, Cancellation Disputes, Industrial Design Rights.

\section{Introduction}

Intellectual property rights are legal rights relating to the problem of the findings and creativity of a person or persons related to the protection of reputation issues in the commercial field and actions / services in the commercial field. Intellectual property rights in the industrial sphere are referred to as Industrial Property Rights. Industrial ownership consists of patents, models 
International Journal of Innovation, Creativity and Change. www.ijicc.net

Volume 10, Issue 5, 2019

and designs, industrial designs, trademarks, trade names, sources of marks or origin designations.

Industrial design is one of the Industrial Property Rights that continues to develop. Industrial design is a creation of a shape, configuration, or composition of lines or colours, or lines and colours, or a combination thereof in the form of three dimensions or two dimensions that gives an aesthetic impression which can be realised in three-dimensional or two-dimensional patterns. Further, it can be used to produce a product, item, industrial commodity or handicraft. The development of industrial design requires continuous creativity and innovation. The originality of an industrial design is one of the topics that is often questioned when there is a product whose design has certain similarities to the design of another similar product. Actors of Intellectual Property Rights are those who create something, design something, or produce other activities. The state will usually give exclusive rights to individuals, each a perpetrator of Intellectual Property Rights. Granting this exclusive right is as a token of appreciation for the work of creativity.

Departing from this, the issue of protection of Industrial Designs is an inseparable problem in the framework of free trade. In its development, Industrial Design plays an important role for the success of industry and trade in a country. Industrial Design is a means to get high economic added value in an industry. Therefore, developed industrial countries such as the United States, United Kingdom, and Japan have given special attention to industrial design (Mayana, 2004).

The attitude of the people who still consider IPR as a public right has resulted in the implementation of legal protection against industrial designs often not working properly. So that ownership rights' disputes over industrial designs often occur because many designs are not registered properly, for example, industrial designs that have similarities with other industrial designs which have also been accepted by the Directorate General of IPR registration (Kusumaningrum dan Roisah, 2016).

Design is a form of a person's work as a result of his intellectual ability, which is manifested not only in the form of work on paper, but has already been formed in the tangible form of an object that has a beneficial value for human life. The manifestation of these benefits, especially those concerning the results of industrial design, can be felt after undergoing the stages of the production process, either through ordinary handwork or in the home industry and mass fabrication processes, all done by the person, with the aim of obtaining additional economic value (Djumhana, 1999).

The results of a creation are not automatically obtained by the rights' holder, but the law provides provisions regarding the Protection of Rights. Industrial Design is granted by the Republic of Indonesia through the Ministry of Law and Human Rights cq, Directorate of Intellectual Property Rights cq and the Director of Industrial Design. Industrial Design is 
International Journal of Innovation, Creativity and Change. www.ijicc.net

Volume 10, Issue 5, 2019

requested through the registration procedure by the applicant or legal entity entitled to the industrial design, to the Director of Industrial Design.

Registration of industrial design in order to obtain legal protection, is the implementation of the principle of the first registrant, which means that the first person submits an application for the right to industrial design that will get legal protection and is not based on the principle of the first person to design. The registration of industrial design is very essential, requiring the accuracy and professionalism of the Directorate of Intellectual Property Rights in the context of research or verification of registrations carried out by industrial design applicants, because of their impact on fair business competition and as a form of consumer protection.

The right to industrial design will be granted if it meets new or novelty elements. The novelty element means that the results of a new creation are first submitted and at the time of registration there is no other party that can prove that the registration is not new or there has been a prior disclosure or publication, both in writing and not in writing. In addition to the novelty element in granting industrial design rights, it can also develop an existing industrial design by adding configurations, shapes, line and colour compositions, or lines and colours, or a combination of the two.

In this regard, it is necessary to pay attention to the provisions of Article 2 paragraph (1) and (2) of the Industrial Design Law which states that:

"Industrial design rights are granted for new industrial designs and industrial designs that are considered new if on the date of receipt of the industrial design is not the same as pre-existing disclosures".

The explanation of this article states that what is meant by disclosure is disclosure through print or electronic media including participation in an exhibition. Whereas the previous disclosures referred to above are disclosures of industrial designs made before the date of receipt or priority date, if the application is submitted with priority rights or has been announced, used in Indonesia or outside Indonesia (Isnaini, 2010).

Applicants for industrial design rights that have fulfilled all administrative requirements and fulfilled all elements specified in the law will receive an Industrial Design Certificate. A person or legal entity that has obtained an Industrial Design Certificate will obtain an exclusive right to use the industrial design rights that it already has, and prohibit other people without their consent from making, using, selling, importing, exporting, or circulating goods that are given the right to industrial design. The importance of registration and protection of designers is because industrial designs have characteristics that are easily remembered by consumers, where industrial designs have the distinctive power of comfort, functionality and quality that consumers will obtain from these industrial designs. 
International Journal of Innovation, Creativity and Change. www.ijicc.net

Volume 10, Issue 5, 2019

The Industrial Design Law also regulates violations regarding industrial design that have been categorised in the civil and criminal domains, but the regulation is still weak, so there are many disputes between holders of industrial design certificates that are both issued by the Ministry of Law and Human Rights Manusia Republik Indonesia cq, Directorate General of Intellectual Property Rights cq and Director of Copyright Design, Industrial Design, Layout Design of Integrated Circuits and Trade Secrets, hereinafter referred to as Director of Industrial Design. The number of disputes is evidence of the weakness of the Industrial Design Law. Between industrial design rights' holders who both have industrial design certificates, it turns out that in the future there are similarities with each other, while the owners of industrial design certificates do not intend to copy, fake or copy each other. They have registered their respective industrial designs according to the procedure determined according to the Industrial Design Law, but in the future both criminal disputes occurred by reporting to the Police and also civilly by filing a lawsuit for canceling the Industrial Design Certificate at the Commercial Court. This is due to industrial players who register industrial designs that have been used or have been announced (the same as pre-existing disclosures), even though they are included in industrial designs that have become public domain, so that the application for registration should be rejected by the Directorate General of Intellectual Property.

The characteristics of industrial design that have become public property are closely related to the novelty of a design. Therefore, the principle of novelty is a legal principle that also needs attention in protecting the right to industrial design (Dewanti, 2019). Only designs that are truly new, can be given rights. The newness value can be measured through several elements such as a combination of existing designs, or designs that are indeed different from the previous ones. In this case, our law does not regulate further what is the measure of novelty itself.

\section{Results and Discussion}

\section{Public Domain in the Exclusive Right to Industrial Design}

Before entering into the discussion of substance about the Public Domain relating to exclusive rights in industrial design, the Public Domain in IPR is first described. IPR protection provides exclusive rights for its owners. Exclusive rights are rights that are only given to IPR holders for a certain period of time, exercising their rights themselves or giving permission to other parties to have their rights, thus, other parties are prohibited from carrying out such IPR without the owner's consent. IPR owners have the exclusive right to implement IPR owned and to prohibit other people without their consent to make, use, sell, import, export and / or distribute the intended goods.

Excluded from the provisions of exclusive rights is the use of IPR for research and education purposes, as long as it does not harm the reasonable interests of IPR holders. The use referred to herein is the use only for the reasonable interest of the owner of the said right. What is meant by fair interest is the use for the purposes of education and research in general. In the field of education, for example, the reasonable interests of the right owner will be harmed if used for 
International Journal of Innovation, Creativity and Change. www.ijicc.net

Volume 10, Issue 5, 2019

all educational institutions in the city. The criterion of importance is not solely measured by the presence or absence of commercial elements, but also of the quantity of use.

This exclusive right is not granted indefinitely, but is limited and after that period there is no more rights and it becomes a public domain (public property), so that everyone can use the industrial design without paying royalties. Public Domain as defined epistemologically is where Public means open or available for everyone to use, share, or enjoy it, while the Domain is defined as perfect and absolute ownership of the area. In terms according to the Black's Law Dictionary, the public domain is the whole of IPR material that is not protected by the IPR Law and is available for everyone to use free of charge (Garner, 2004).

Commercial Court Jurisprudence through Decision Number 40 Industrial Design / 2007 / PN.Niaga.Jkt.Pst On August 30, 2007, stated that Industrial Designs that are known to the public (Public Domain) are Industrial Designs that have been published before the date of receipt of an application.

According to James Boyle, Public Domain is IPR material that is not protected by the IPR regime. The material entered into the Public Domain area may be because it is not biased to be owned individually. Another possibility is because the protection period has ended. For example, the works of the poet Shakespeare. Some of the definitions of the Public Domain are even more detailed. IPR material that is still protected by IPR, also has a Public Domain aspect but is limited only to a reasonable interest, limited to research and education purposes (Boyle, 2008).

The IPR material in the Public Domain can be used at will by other parties, but with the condition that the name of the inventor / creator / designer of the work must be stated. Work and inventions in the public domain are considered part of the public cultural heritage, and anyone can use them without restrictions. It must be remembered that when an IPR material has entered the public domain area, then what ends is the economic right of the IPR material, but the moral rights of a work have no time limit and are ongoing.

From the discussion on the Public Domain above it can be concluded that the Public Domain is IPR material that is not protected by IPR Law. These IPR materials cannot be protected because of several reasons. One reason is that these IPR materials are not new or previously published IPR materials, or the IPR material has not been registered or protected by law.

An IPR can be seen as a product of the culture of human civilisation. When the protection of the IPR is ended, the IPR which owns it individually will switch to become a common property. Everyone will be free to own / use IPR that has entered the public domain area. The IPR may not be claimed for protection. Claims on IPR protection that have entered the public domain area will be denied by the authorities. 
International Journal of Innovation, Creativity and Change. www.ijicc.net

Volume 10, Issue 5, 2019

With regard to the Public Domain in Industrial Design, it is not much different from other IPRs. In registration, industrial design rights can only be granted for new industrial designs. This means that industrial design that is not new, or biased to say that industrial design that is generally not biased to be registered. The UUDI in the explanation referred to by the new design means that the design is not the same as an existing disclosure, has not been announced or used in Indonesia or outside Indonesia. The meaning of "new" or "newness" is determined by a registration that was first submitted and at the time the registration was submitted. No other party can prove that the registration is not new or there has been a prior disclosure / publication, whether written or unwritten, for industrial designs that have received protection. The protection period is given for 10 (ten) years from the date of receipt. After a period of 10 (ten) years, the industrial design will become public property.

Previously, in the Constitution or PP regarding Industrial Design, the term Public Domain was not found. However, in Government Regulation No. 1 of 2005 concerning Industrial Design, in the explanation of Article 24 paragraph (1) letter b, there is a problem of public ownership in industrial design, which is public ownership such as traditional crafts or art works that have been published and others. According to the Jurisprudence Panel of Judges at the Commercial Court, that the notion of Public Domain is public property (Decision Number 49 / Industrial Design / PM.Niaga.Jkt.Pst), the term general ownership is the same as the Public Domain term.

It can be concluded that industrial designs that have become public property or Public Domain consist of two types: firstly, the industrial design has never been registered with the Director General of Intellectual Property, and secondly, the design has been registered before but has passed the protection period. Therefore, designers must be demanded to be active so that industrial design does not become public property. Because industrial design rights are born because of registration, there is no industrial design rights that are born automatically when the industrial design is created.

\section{Novelty Elements in Settlement of Industrial Design Cancellation Disputes}

The Industrial Design Law has a fairly good concept and purpose, but factually based on empirical findings, a number of socio-juridical obstacle issues are found regarding the substance of the Industrial Design Law. Categorically, there are three groups of problems namely concerning the formulation of articles, procedures and costs, as well as a matter of protected goals and interests. Newly created industrial designs need legal protection so that the originality and ownership of the designs can be maintained. There are several requirements for obtaining legal protection for an industrial design.

The industrial design requirements that obtain legal protection include the following:

a. Meet the substance requirements 
International Journal of Innovation, Creativity and Change. www.ijicc.net

Volume 10, Issue 5, 2019

1) Creation of industrial designs that give aesthetic impression (Article 1 of Law No. 31/2000). Creative shapes, configurations, line and colour compositions or combinations that give an aesthetic impression. His/her creation is not merely functional or technical (Article 25 (1) TRIPs agreement);

2) Creation of industrial designs that can be seen with the naked eye. Typically, an industrial design creation must be clearly visible (without using tools), where the pattern and shape are clear. So, the beautiful / aesthetic impression is determined through sight, not taste, smell and sound;

3) Creation of industrial designs that can be applied to industrial products and handicrafts (Article 1 of Law no. 31/2000), and can be mass produced through machines or hands. If reproduced it gives consistent results;

4) Creation of new industrial designs (Article 2 (1) of Law No. 31/2000). This is not the same as disclosures that existed before the date of receipt or priority date (if with priority rights) and have been announced / used both in Indonesia or outside Indonesia (Article 2 (2) and Article 2 (3) of Law No.31 / 2000). Newly assessed from the point of creation and / or products. Similarity values, creativity values, and individual character values of an industrial design are not regulated in Law No.31 / 2000. New value / novelty means that the value is not identical or different or not the same or not identical to the "disclosure" that has existed before;

5) Creation of industrial designs that do not conflict with applicable laws, public order, religion or decency (Article 4 of Law no. 31/2000).

b. Meet administrative requirements / formalities: (Article 11, 13, 14, 15, 16, 17 and Article 19 (1) of Law no.31 / 2000)

c. The application is not withdrawn (because it meets the requirements of the petition - Article 20 (1) and the Petitioner does not withdraw the application Article 21 of Law No.31 / 2000).

So that the application for industrial design registration can be given (granted), it make sure the above requirements are met. New value or novelty can be obtained by continuing to develop and look for as many differences as possible to existing designs.

In Article 3 of Law No. 31 of 2000 concerning industrial design, it is explained that an industrial design is not considered to have been announced if within a period of 6 (six) months prior to the date of receipt, and the industrial design:

1) Has been performed in a national or international exhibition in Indonesia or outside Indonesia that is official or officially recognised.

2) Has been used in Indonesia by designers in a series of trials with the aim of education, research and development.

The subjects in industrial design are the designers or those who receive the rights from the designer. Designers according to the provisions of article 1 paragraph (2) UUNo.31 of 2000 
International Journal of Innovation, Creativity and Change. www.ijicc.net

Volume 10, Issue 5, 2019

concerning industrial design, are one or several people who produce an industrial design. Protection of industrial design can be obtained through a registration system, where a designer obtains legal protection for his work or obtains industrial design rights if his party has registered the design work to the Directorate General of IPR, in accordance with the provisions applicable to Law No.31 of 2000 concerning industrial design.

A claim for cancellation of industrial design registration may be filed by an interested party for the reasons referred to in Article 2 or Article 4 of the Industrial Design Law. The decision of the commercial court is submitted to the Directorate General of Intellectual Property Rights no later than 14 (fourteen) days after the date of the decision. Cancellation of industrial design registration eliminates all legal consequences relating to industrial design rights and other rights derived from such industrial designs (Boyle, 2008).

Every application for cancellation of registration of Industrial Designs as referred to in Article 44 of Government Regulation of the Republic of Indonesia Number 1 of 2005 concerning the Implementation of Law 31 of 2000 concerning Industrial Designs must be completed:

a) Industrial Design Certificate;

b) Written objection letter which is not an objection from the Design Rights License Recipient;

c) Industries registered in the General Register of Industrial Designs;

d) $\mathrm{S}$ pecial power of attorney for the cancellation of the application for registration of Industrial

Designs, if submitted by their Proxy; and

e) P roof of payment of Application for cancellation of registration of Industrial Designs.

Pursuant to Article 38 of the Industrial Design Law, a claim for cancellation of an industrial design can be submitted by interested parties through the Commercial Court on the grounds that the industrial design is the same as the pre-existing disclosures and other reasons, namely that the industrial design is contrary to applicable laws, public order, or decency.

The procedures that must be followed as a procedure for filing a lawsuit are as follows (Saidin, 1995):

1) A claim for cancellation of an industrial design shall be submitted to the head of the Commercial Court in the jurisdiction of the defendant's residence or domicile.

2) In the case of the defendant residing outside the territory of Indonesia. The lawsuit was submitted to the chairman of the Central Jakarta Commercial Court.

3) The Registrar registers the cancellation claim on the date the claim is filed to the plaintiff and is given a written receipt signed by the court clerk with the same date as the date of lawsuit registration.

4) The Registrar submits a claim for cancellation to the head of the Commercial Court within a maximum period of 2 (two) days from the date of registration.

5) Within a maximum period of 3 (three) days from the date the claim for cancellation is registered. The Commercial Court studies the lawsuit and sets the day of the trial. 
International Journal of Innovation, Creativity and Change. www.ijicc.net

Volume 10, Issue 5, 2019

6) The hearing of the cancellation claim is held within a period of no later than 60 (sixty) days after the lawsuit is registered.

7) Summons of the parties is carried out by the bailiff no later than 7 (seven) days after the cancellation claim is registered.

8) Decisions on a claim for cancellation must be pronounced no later than 90 (ninety) days after the lawsuit is registered and can be extended no later than 30 (thirty) days with the approval of the Supreme Court.

9) The decision on the claim for cancellation that contains the full legal considerations underlying the decision must be pronounced in a hearing open to the public and can be carried out first, even though a decision was filed against a decision.

10) A copy of the decision of the Commercial Court must be submitted by the bailiff to the parties no later than 14 (fourteen) days after the decision on the cancellation claim is pronounced.

The decision to cancel the industrial design right is notified in writing by the Directorate General of Intellectual Property Rights to the industrial design right holder. If the design right has been licensed in accordance with the records in the general list of industrial designs, and the party submitting the cancellation by stating that the industrial design rights that have been granted, are declared not valid again from the date of the cancellation decision.

In cases that enter the Commercial Court relating to industrial design rights, the focus of the debate is on proving the element of novelty. This happened to the Central Jakarta Commercial Court, which has twice postponed the hearing to cancel the registration of the industrial design of the pipeline. Registered since June 8, three business operators in West Jakarta, Mimin, Adi Dharma Kurniawan and Dani, filed a lawsuit against H. Syamsu Syah Alam and the Directorate General of Intellectual Property at the Ministry of Law and Human Rights. The plaintiffs felt disadvantaged over the issuance of the industrial pipeline design rights by the Director General of Information Commission to the defendant.

Article 38 of Law Number 31 Year 2000 concerning Industrial Designs, provides an opportunity for parties who feel an interest to sue registered industrial designs. The cause of the lawsuit is generally related to the newness requirements referred to in Article 2 of the same Law. Under this article, industrial design rights are granted for new industrial designs. An industrial design is considered new if on the date of receipt, the industrial design is not the same as the previous disclosure. The disclosure can be seen in print or electronic media, including participating in exhibitions.

In practice, translating novelty is not always easy. Evidenced by the industrial design cases that have led to the Supreme Court. Of the 769 , the special civil cases that were received by the Supreme Court in 2014, were only 44 IPR cases (5.72\%). Even then, most of them were brand matters. In several industrial design cases decided before 2014, it seems clear that the focus of the debate generally revolves around the element of novelty as in Article 2 and Article 4 of the 
International Journal of Innovation, Creativity and Change. www.ijicc.net

Volume 10, Issue 5, 2019

Industrial Design Law. The novelty is related to the shape, configuration, or composition of lines or colours, or their combination. Article 4 states that industrial design rights cannot be granted if the proposed industrial design is contrary to the applicable laws and regulations, public order, religion or decency.

Decision on cassation regarding the disk design industry, Mahkama Agung stated that the industrial design owned by the defendant was not new because it did not differ significantly from the disk space produced and traded by the plaintiff earlier than the date of receipt of the defendant's registration. In the TIP REFIL BALLPOIN industrial design decision, the cassation panel stated that judex facti was not sufficient to give consideration about the exact fact between the two disputed products. Judex facti is considered wrong to consider the novelty element because of the fact that the novelty element was completely invisible. The Supreme Court rejected the petition for a review of this case.

Another example is the case of the design of the carpet industry with pillar motifs and carpets with mosque motifs. The Supreme Court rejected the appeal filed by the plaintiff. In consideration the Supreme Court stated that the defendant was the first registrant of industrial design and thus had to obtain legal protection, while the plaintiff did not register his industrial design so that he could not formally obtain legal protection. According to the assembly, the legal protection of the defendant's registered industrial design is not on the motifs of the pillars and mosques, but on parts that are specific to the shape, configuration or composition of lines or colours or combinations thereof, which can give an aesthetic impression on the carpet.

However, in the case of the New China Diesel Genuine Parts Packaging Box Gear Set NP packaging industry, the cassation assembly overturned the judex facti ruling because of the novelty issue. The Supreme Court stated that because a new understanding of an industrial design is not only determined by the registration that was first proposed, but also that there must be no other party that can prove that the registration is not new, or there have been previous disclosures / publications both written and unwritten.

In another case, regarding the Jagged Plastic Clip Bag, the cassation assembly considered that the design of the serrated plastic clip bag on behalf of the defendant had been produced and marketed for the original claimant before the date of receipt of the industrial design request on behalf of the defendant, so that the industrial design submitted by the defendant was not a new design. Moreover, it was proven at the trial that the Directorate General of Intellectual Property Rights did not conduct a substantive examination.

\section{Conclusion}

Industrial designs that have become Public Domains are categorised in industrial designs not through the registration process with the Director General of Information Technology or previously disclosed in the form of publications and industrial design through the registration 
International Journal of Innovation, Creativity and Change. www.ijicc.net

Volume 10, Issue 5, 2019

process to the Director General of Information Technology, but ending in protection of economic rights of 10 (ten) years.

Evaluation of an element of novelty is in the comparison between designs that have become Public Domain and designs that become objects in dispute resolution. This is because the notion of equality in essence in an industrial design can be translated as an element that does not have a significant difference, either the shape, configuration or composition of lines and colours or combinations thereof. Although there are still many different interpretations of the similarity in principle; for example, the similarity in an industrial design can be said to be the same or must be really similar in terms of both the shape, configuration, or composition of lines or colours or a combination thereof. Thus, it can be said that an industrial design has similarities in principle with other industrial designs. However, the element of similarity in essence in industrial design is aesthetic form and impression, which means that industrial design can be seen in plain view does not have a significant difference. 
International Journal of Innovation, Creativity and Change. www.ijicc.net Volume 10, Issue 5, 2019

\section{REFERENCES}

Boyle, J. (2008). The Public Domain: Enclosing the Commons of the Mind, Yale University Press.

Dewanti, L. I. (2019). Legal Test Kebaruan (Novelty) Dalam Desain Industri, httpis:n//alidoenwaanti.blogspot.com/2009/03/legal-test-kebaruan-novelty-dalam.html

Djumhana, M. (1999). Aspek-Aspek Hukum Desain Industri di Indonesia, Bandung, Indonesia: Citra aditya Bakti.

Garner, B. (2004). Black's Law Dictionary: Eight Edition. St. Paul: Thomson-West.

Isnaini, Y. (2010). Buku Pintar HAKI, Bogor, Indonesia : Ghalia Indonesia.

Kausarian, H., Sri Sumantyo, J. T., Kuze, H., Aminuddin, J., \& Waqar, M. M. (2017). Analysis of polarimetric decomposition, backscattering coefficient, and sample properties for identification and layer thickness estimation of silica sand distribution using L-band synthetic aperture radar. Canadian Journal of Remote Sensing, 43(2), 95-108.

Kausarian, H., Sumantyo, J. T. S., Kuze, H., Karya, D., \& Panggabean, G. F. (2016). Silica Sand Identification using ALOS PALSAR Full Polarimetry on The Northern Coastline of Rupat Island, Indonesia. International Journal on Advanced Science, Engineering and Information Technology, 6(5), 568-573.

Kausarian, H., Batara, B., Putra, D. B. E., Suryadi, A., \& Lubis, M. Z. (2018). Geological Mapping and Assessment for Measurement the Electric Grid Transmission Lines in West Sumatera Area, Indonesia. International Journal on Advanced Science, Engineering and Information Technology, 8(3), 856-862.

Kusumaningrum, D. A. dan Roisah, K. (2016). Implementasi Penilaian Kebaruan dan Prinsip Itikad Baik dalam Perlindungan Desain Industri, Jurnal Law Reform, Volume 12, Nomor 2.

Mayana, R. F. (2004). Perlindungan Desain Industri di Indonesia Dalam Era Perdagangan Bebas Jakarta, Indonesia : Gramedia Widiasarana Indonesia.

Muhammad, A. (2001). Kajian Hukum Ekonomi Hak kekayaan Intelektual, Bandung, Indonesia: Citra Aditya Bakti.

Saidin, O. (1995). Aspek Hukum Hak kekayaan Intelektual (Intellectual Property Rights), Jakarta, Indonesia: Raja Grafindo Persada.

Soekanto, S. (2006). Penelitian Hukum Normatif Suatu Tinjauan Singkat, Jakarta, Indonesia: Raja Grafindo Persada. 
International Journal of Innovation, Creativity and Change. www.ijicc.net Volume 10, Issue 5, 2019

Yuliasih, (2015). Perlindungan Hukum Desain Industri Dalam Pelaksanaan Prinsip Keadilan Menurut Teori Keadilan John Rawls (Studi Kasus Putusan Nomor 35 PK/PDT.SUSHKI/2014). Jurnal Notarius, Edisi 08 Nomor 2. 